Karstenia 51: 1-16, 2011

\title{
New and noteworthy records of Pezizomycetes in Sweden and the Nordic countries
}

\author{
IBAI OLARIAGA and KAREN HANSEN
}

\begin{abstract}
OLARIAGA, I. \& HANSEN, K. 2011: New and noteworthy records of Pezizomycetes in Sweden and the Nordic countries. - Karstenia 51: 1-16. Helsinki. ISSN 0453-3402.

Pezizomycetes are poorly known in Sweden compared to the rest of the Nordic countries. Field inventories to improve the knowledge of Pezizomycetes in Sweden were therefore carried out during 2008-2010 in selected areas. Nine new or remarkable species are included in this first contribution, among which five are new to Sweden and two to the Nordic countries. Byssonectria fusispora has not previously been known or accepted in the Nordic countries. We compare it directly to B. terrestris using fresh material and give distinguishing characters. Chalazion sociabile is new to Sweden and this is the first report outside Norway. Three Scutellinia species are presented for the first time for Sweden, S. citrina, S. macrospora and S. torrentis. A deviant $S$. torrentis collection with larger and finely ornamented spores is described in detail and compared to other collections of $S$. torrentis (including an isolectotype) and $S$. superba. The report of $S$. superba is the second for Sweden. The first Nordic and second European record of Paratrichophaea michiganensis is presented. The genus Spooneromyces is reported for the first time in Sweden, with $S$. helveticus as new to the Nordic countries, and $S$. laeticolor new to Sweden. Detailed descriptions are provided, drawing attention to in vivo characters, with colour macro- and microscopic photos of the species. Species delimitations are discussed, and ecology and known distribution for each species are given.
\end{abstract}

Key words: Ascomycetes, Pezizales, Pyronemataceae, operculate discomycetes, vital taxonomy, biodiversity

Ibai Olariaga, Department of Cryptogamic Botany, Swedish Museum of Natural History, P.O. Box 50007, SE-104 05, Stockholm, Sweden; e-mail: ibai.olariaga@nrm.se

Karen Hansen, Department of Cryptogamic Botany, Swedish Museum of Natural History, P.O. Box 50007,SE-104 05, Stockholm, Sweden; e-mail: karen.hansen@nrm.se

\section{Introduction}

The class Pezizomycetes (operculate discomycetes) is relatively well known in the Nordic countries, compared to the rest of the world. Species have been collected and studied in Denmark, Norway and Finland by several mycologists during the last 45 years (e.g. Dissing 1966, Eckblad 1968, Schumacher 1979, Dissing \& Sivertsen 1983, Schumacher \& Jenssen 1992, Kristiansen 2006, Harmaja 2009). In Sweden, however, no specialist has focused on this group, although Nannfeldt published a number of smaller papers (Nannfeldt 1937, 1938, 1949, 1966). Recently, in a checklist of the non-lichenized ascomycetes of
Sweden, 276 Pezizomycetes species were reported for the country (Eriksson 2009). Compared to the number of species recorded from the Nordic countries (i.e. Denmark, Finland, Iceland, Norway and Sweden), ca 470 species (Dissing et al. 2000), many are still to be found in Sweden, considering the country's large size and wide range of habitats. To improve the knowledge of the diversity and distribution of Pezizomycetes in Sweden, broad field-inventories were initiated in 2008 under the research project "Pezizomycetes in Sweden, focusing on Pezizaceae and Pyronemataceae", funded by the Swedish Taxonomy Initiative. The fieldwork targeted areas that potentially could have a high diversity 
of taxa of Pezizomycetes, e.g. calcareous and/ or disturbed ground (with a high $\mathrm{pH}$ and often low content of organic matter; Petersen 1985) and areas only little or not previously explored. This paper presents the first nine of these new or rarely reported species discovered from Sweden or the Nordic countries. Although higher-level relationships have been clarified within Pezizomycetes (see Hansen \& Pfister 2006), many problems remain to be solved at generic and species level.

The aim of this paper is to contribute to the understanding of the limits and variability of these scarcely known species, by providing detailed morphological descriptions and photographs, including more complete information on characters in living condition, especially guttulation and pigmentation in spores and paraphyses (vital taxonomy; Baral 1992), and information on ecology and distribution.

\section{Materials and methods}

Apothecia were studied using bright field optics and differential interference contrast (DIC) light microscopy. Macro- and microscopic descriptions, except for the excipulum structure and hairs, were made from fresh material, and were completed later from dried material rehydrated in $\mathrm{H}_{2} \mathrm{O}$ for at least 3 hours. Mature spores, discharged from the asci without applying external pressure on the cover slip, were measured from fresh and rehydrated material in $\mathrm{H}_{2} \mathrm{O}$. Unless otherwise stated, the spore dimensions (excluding ornamentation) and the calculated mean values are based on 20 spores measured from each collection $\left(\times 1000\right.$ magnification): mean length $\left(\mathrm{L}_{\mathrm{m}}\right)$, mean width $\left(\mathrm{W}_{\mathrm{m}}\right)$ and length : width ratio $\left(\mathrm{Q}_{\mathrm{m}}=\mathrm{L}_{\mathrm{m}} / \mathrm{W}_{\mathrm{m}}^{\mathrm{m}}\right)$. " $n$ " refers to the number of collections that the statistics are based on. Extreme values are given in parentheses. Mounting reagents used were Congo red in ammonia (CR), Cotton blue in lactic acid (CB) and Melzer's reagent (MLZ). The symbol * refers to fresh material and $\uparrow$ to dried, rehydrated material. Microanatomical terminology follows Korf (1973). Geographic coordinates in decimal grades, obtained from Google maps, are given for some of our collections. The newly collected material will be deposited in the Swedish Museum of Natural History (S).

\section{Results and discussion}

Byssonectria fusispora - Fig. 1, a-d Byssonectria fusispora (Berk.) Rogerson \& Korf in Korf, Phytologia 21: 202. 1971.

$\equiv$ Peziza fusispora Berk., London J. Bot. 5: 5. 1846.

Apothecia $1-5 \mathrm{~mm}$ diam, initially globose, cleistohymenial, opening prior to spore maturation, then urniform and finally shallowly cup-shaped, sessile, gregarious to weakly caespitose. Margin distinct, with remnants from the opening of the excipular roof, in young apothecia appearing rimmed. Hymenium bright reddish orange. Outside furfuraceous, with small scale-like tufts, especially evident in younger apothecia. Subiculum formed by sparse hyphal threads, more conspicuous among densely clustered apothecia. Asci cylindrical, thin-walled, 8-spored, 201-230 $\times 10-13 \mu \mathrm{m}$, base pleurorhynchous. Ascospores uniseriate, fusiform, inequelateral, smooth, $\uparrow 21-$ $24.5 \times 7-8.5 \mu \mathrm{m}\left(\mathrm{L}_{\mathrm{m}}=22.8, \mathrm{~W}_{\mathrm{m}}=7.7, \mathrm{Q}_{\mathrm{m}}=2.94\right.$, $\mathrm{n}=1)\left[* 23-25.5 \times 7-8 \mu \mathrm{m}, \mathrm{L}_{\mathrm{m}}^{\mathrm{m}}=23.6, \mathrm{~W}_{\mathrm{m}}=7.6\right.$, $\left.\mathrm{Q}_{\mathrm{m}}=3.10\right]$. *Content with two large guttules and many small ones, wall thickened and refractive at the poles. Paraphyses simple, 3.5-4.5 $\mu \mathrm{m}$ broad, gradually enlarged towards apices, up to $5-8 \mu \mathrm{m}$ broad, narrowly claviform to claviform, straight to very slightly bent, sparsely septate. ${ }^{*}$ Content of very small, deep reddish orange guttules, sometimes leaving a hyaline area at the apex, with more sparse guttules towards the base, turning bluish-greenish black in MLZ. Medullary excipulum not clearly differentiated, composed of thin-walled, hyaline, angular - elongated cells, 18-43 × 10-20 $\mu \mathrm{m}$, with abundant yellow - orange vacuoles. Ectal excipulum ca 80-100 $\mu \mathrm{m}$ thick, of textura globulosa-angularis, cells 23-55 $\mu \mathrm{m}$ diam, thin-walled, hyaline, clearly reddening in MLZ. Hyphal hairs arising from outermost globose cells of the outer excipulum, cylindrical, straight, hyaline, thick-walled except at apices, 109-360 × 9.5-12 $\mu \mathrm{m}$. Anchoring hyphae similar to the excipular hairs, but longer. Subiculum hyphae cylindrical, slightly sinuous, thin-walled to thick-walled, with scarce septa, hyaline to light yellowish, smooth, 7-13 $\mu \mathrm{m}$ diam, slightly reddening in MLZ. 
Specimens studied: SWEDEN. Södermanland. Österhaninge, Tyresta National Park, N59.179996, E18.293116, in path on sandy acidic ground, in open area that burned in 1999, 27.IV.2010 Olariaga, KH.10.01 (S); same locality, 2.V.2010 Olariaga, KH.10.06 (S).

Specimens studied for comparison. B. terrestris: SWEDEN. Uppland. Jumkils, Styggekärrets naturreservat, Hasseldalarna, in Picea forest, amongst elk dung, 9.V.2010 Hansen \& Olariaga, KH.10.05 (S).

Byssonectria P. Karst. is characterized by cleistohymenial development (Fig. 1b) of the apothecia that open during the mesohymenial phase, fusiform spores with thickened walls at the poles (Fig. 1c, e), the presence of a more or less developed subiculum and the occurrence in nitrogenrich places or on burned ground. Except for $B$. terrestris (Alb. \& Schwein.) Pfister, species of the genus appear to be rare and rather poorly known.

Byssonectria fusispora has been treated as a separate species from the well-known $B$. terrestris (syn. Byssonectria aggregata [Berk. \& Br.] Rogerson \& Korf) by some authors (Svrček 1969, Pfister 1993, Yao \& Spooner 1996), although Yao \& Spooner (1996) questioned the distinguishing characters. Pfister (1993) separated $B$. fusispora from B. terrestris on the basis of poor development of the subiculum, larger spores and apothecia (up to $6 \mathrm{~mm}$ diam), and occurrence on soil, particularly in areas with charred wood, in contrast to dung and plant debris where animals have urinated. Yao \& Spooner (1996) stated that the development of the subiculum depends on the substratum; on soil a very weak subiculum will develop, whereas on plant litter or debris the subiculum will be strikingly thick. Rifai (1968) recognized only one variable species of Byssonectria (as Inermisia), based on examination of type material of several names, including B. fusispora from Tasmania (Berkeley 1846) and B. aggregata from England (Berkeley \& Broome 1866), and additional collections. As Pfister (1993) we consider Rifai's concept too heterogeneous. Measured from the illustration of the type of B. fusispora (Rifai 1968: Fig. 220), the spore ranges $(25.3-27.3 \times 8.3-9.7 \mu \mathrm{m})$ are within those mentioned by Pfister $(23-28 \times 7.2-11 \mu \mathrm{m})$. Nevertheless, Yao and Spooner (1996) claimed the spores of the type to be mostly $21-23 \times 8-9 \mu \mathrm{m}$. Studies of fresh material and freely discharged spores have been called for to solve or interpret the species boundaries of $B$. fusispora and B. aggregata (Pfister 1993, Yao \& Spooner 1996).
During the spring of 2010 we were able to study fresh material that was attributed to both species, and thus to make a direct comparison of delimiting characters. Byssonectria fusispora differed from $B$. terrestris (Fig. 1e-f) in having larger, reddish, shallowly cup-shaped apothecia (Fig. 1a); longer and narrower spores (Fig. 1c); along with straight paraphyses with darker reddish orange guttules (Fig. 1d). The subiculum of $B$. fusispora was very weakly developed and mostly visible among tightly growing fruitbodies, while it was very conspicuous and thick in $B$. terrestris. As Benkert (1987) and Yao \& Spooner (1996) claimed, this could be related to the substrate. For a summary of the differences see Table 1. Boudier's (1905-10) pl. no. 394 illustrates $B$. fusispora well. Although more fresh collections should still be studied and the boundaries assessed by molecular data, our material of $B$. $f u$ sispora agrees with the descriptions provided by Pfister (1993) and Yao \& Spooner (1996), and we agree with these authors that B. fusispora and $B$. terrestris constitute two separate species. Spore measurements of $B$. fusispora obtained from dried material, however, are smaller than those cited by Pfister (1993) and inferred from Rifai (1968).

Only one species of Byssonectria, B. terrestris, has been known in the Nordic countries following Dissing et al. (2000). Eriksson (2009) listed $B$. fusispora as a synonym of $B$. terrestris. According to Pfister (1993), B. terrestris seems to be exclusively boreal or high montane, whereas $B$. fusispora occurs most often in middle latitudes. Thus, $B$. fusispora may be rare in the Nordic countries which could explain why only one species has been recognized or accepted so far. Byssonectria terrestris is, on the other hand, occasional to common in the Nordic countries (Dissing et al. 2000).

\section{Chalazion sociabile} - Fig. 1, g-j Chalazion sociabile Dissing \& Sivertsen, Norweg. J. Bot. 22: 2. 1975.

Apothecia up to $500 \mu \mathrm{m}$ diam, pulvinate, sessile, gregarious. Margin inconspicuous, light greyish white, when dry light yellowish ochre. Outside glabrous. Asci clavate, thin-walled to slightly thick-walled, 8-spored, with a large operculum, $125-158 \times 30-40 \mu \mathrm{m}$, base very short, narrow, pleurorhynchous. Ascospores uniseriate or bise- 
riate, narrowly ellipsoid, sometimes inequilateral having a straight side, with hemispherical warts, up to $3 \mu \mathrm{m}$ high, sometimes coalescing (up to $4 \mu \mathrm{m}$ long), cyanophilic, $\dagger 30-34 \times 14$ $16 \mu \mathrm{m}\left(\mathrm{L}_{\mathrm{m}}=32.1, \mathrm{~W}_{\mathrm{m}}=15.2, \mathrm{Q}_{\mathrm{m}}=2.12\right)[* 32-34$ $\times 14,5-16,1 \mu \mathrm{m}, 4$ spores]. ${ }^{*}$ Content of many small and refractive guttules; †with one or two large guttules and many smaller ones. De Bary bubbles not observed. Paraphyses gradually enlarged at apices (6.3-8.5 $\mu \mathrm{m}$ broad) and slightly bent, *content hyaline, with some little refractive guttules; †with condensed, collapsed content. Medullary excipulum ca $40 \mu \mathrm{m}$ thick, formed by cylindrical to subglobose cells, forming subparallel rows, thin-walled, yellowish, with refractive guttules, 2-8 $\mu \mathrm{m}$ diam. Ectal excipulum only present at the basal part of the apothecia, of textura subglobulosa, cells yellowish, with refractive content, $8-18 \mu \mathrm{m}$ diam, not reacting in MLZ. Hairs absent.

Specimens studied: SWEDEN. Jämtland. Östersund, Ängsjön naturreservat, N63.177608, E14.583755, on rich mull under tall herbs in a clearing by a Picea forest, 26.VIII.2009 Hansen \& Olariaga, KH.09.70 (S).

Chalazion Dissing \& Sivertsen produces very small fruitbodies for a soil-inhabiting member of the Pezizomycetes (Fig. 1g), which is probably the reason why it is extremely rarely detected in the field and only few records exist. Chalazion sociabile was the first species described in the genus, from Mo i Rana (Dissing \& Sivertsen 1975). Some years later a second species, $C$. helveticum Dissing, was described from the Alps (Dissing 1980). The latter species seems more widespread than $C$. sociabile, since it has been reported from Denmark (Dissing 1983) and eight additional localities in Norway (Kristiansen 1990). On the contrary, $C$. sociabile has only been recorded once after it was described (Kristiansen 1990). This is the first find outside Norway and the third locality for the species. A third species, C. erinaceum Doveri, Yei Z. Wang, Cacialli \& Caroti has not been reported since it was described (Doveri et al. 1998). It is distinguished by a coprophilous ecology and smaller spores.

The Swedish locality is a clearing by a Picea forest, where the rich mull had been turned up some time ago, under e.g. Aconitum septentrionale, Chaerophyllum, Geranium sylvaticum, Tussilago farfara, Urtica dioica and Filipendula ulmaria (Fig. 2). Several other Pezizales species were found at the site, namely Ascobolus viridis Curr., Marcelleina persooni (P. Crouan \& H. Crouan) Brumm. and Trichophaea hybrida (Sow.) T. Schumach., before discovering Chalazion sociabile.

The relationships of Chalazion are still uncertain. It has been considered a member of Pezizales, with a unique position, and was indirectly suggested to belong to Thelebolaceae (Dissing \& Sivertsen 1975) or Pyronemataceae (Dissing 1980). Van Brummelen thought it best placed in Pezizales incertae sedis, but alternatively suggested it be moved to Thelebolaceae, because of the ascus structure (in Dissing \& Schumacher 1994), as Eriksson (1999) did. Molecular data has confirmed the placement within Pezizales (Landvik et al. 1998, Hansen et al. 2005); it nested within a larger group along with Ascodesmidaceae, Glaziellaceae and Pyronemataceae, but without support for an exact placement. Following this it was placed in Pyronemataceae by Eriksson (2000). Our preliminary molecular results suggest it is closely related to Coprotus Korf \& Kimbr. and Boubovia Svrček outside the core of Pyronemataceae (Hansen \& Olariaga in prep.).

Paratrichophaea michiganensis - Fig. 3, a-e Paratrichophaea michiganensis (Kanouse) Pfister, Mycologia 80: 519. 1988.

$\equiv$ Trichophaea michiganensis Kanouse, Mycologia 50: 138. 1958.

Apothecia up to $2 \mathrm{~mm}$ diam, disc-shaped, sessile. Margin indistinct, with long, stiff, brown hairs, extending far beyond the hymenium. Hymenium greyish or brownish white. Outside concolourous, with abundant long, brown hairs, appressed to erect. Asci cylindrical, thin-walled, 4-spored, with 4 aborted spores. Ascospores uniseriate, ellipsoid, smooth, with an irregular gelatinous sheath, $\dagger 19-21.5 \times 11-12.5 \mu \mathrm{m}, 13$ spores [*19-22 × 11-12.5 $\mu \mathrm{m}, 5$ spores]. *Content homogeneous, with central nucleus seen; similar when dried. Paraphyses of uniform width (2-3 $\mu \mathrm{m})$, straight, septate. *Content hyaline, appearing slightly refractive, without guttules. Subhymenium not distinct from the medullary excipulum, with slightly more swollen hyphae. Medullary excipulum of textura intricata, $\uparrow 70$ $100 \mu \mathrm{m}$ thick, with vaguely parallel arranged 
hyphae, thin-walled, hyaline, $2-4.5 \mu \mathrm{m}$, turning light blue in MLZ. Ectal excipulum of textura globulosa-angularis, $80-130 \mu \mathrm{m}$ thick, cells of 22-45 $\mu \mathrm{m}$ diam, thin-walled, hyaline to yellowish. Hairs arising from the medullary excipulum or seldom superficial, acute at the apex, straight, often ventricose, especially hairs at or towards the margin, with simple or sometimes bifurcate bases, receptacular hairs towards the base of the apothecia with bulbous bases $(25-33 \mu \mathrm{m})$, arising from the outer excipulum, dark brown, thickwalled $(2.5-4.5 \mu \mathrm{m})$, with 2-9 septa, $150-618 \times$ 17.5-22 $\mu \mathrm{m}$.

Specimen studied: SWEDEN. Skåne. Verum, Peninsula to Möllerödsnäs, Bokelund, N56.111628, E14.336391, on decomposing Fagus leaves, on rich mull, along forest path, 22.IX.2010 Hansen, Gillen \& Olariaga, KH.10.244 (S).

The Swedish material belongs to Paratrichophaea Trigaux, a genus not previously known from the Nordic countries. It is characterized by eguttulate, smooth spores and simple excipular hairs (Fig. 3b-e), which arise from the medullary excipulum (Pfister 1988). The genus Trichophaeopsis Korf $\&$ Erb is distinguished by two-pronged hairs (a long branch pointing upwards and a shorter one pointing downwards), which arise superficially.

Within Paratrichophaea, P. michiganensis has been separated from $P$. boudieri (Grelet) Bronckers (syn. P. macrocystis Trigaux) on the basis of the 4-spored asci (Pfister 1988, Bronckers 2003). Kanouse (1958) described it, in addition, with smaller apothecia (up to $1 \mathrm{~mm}$ diam) and hairs up to $700 \mu \mathrm{m}$ long (compared to 900 $\mu \mathrm{m}$ in $P$. boudieri), none arising from marginal cells. Kanouse (1958), studying also P. boudieri (sub Trichophaea), pointed out that she had not encountered any other species of which P. michiganensis could be a four-spored variant. If indeed the number of spores in the asci is the only separating character, it is likely that $P$. michiganensis is a 4-spored form of $P$. boudieri. This should be tested using molecular data.

In our material, each ascus consistently contains 4 well-developed spores and 4 aborted spores. The original description gives smaller spores (16-18 × 8-10 $\mu \mathrm{m}$, Kanouse 1958), but upon re-examination of the holotype Pfister (1988) gave larger spores $(21-23[-25] \times 11-13$ $\mu \mathrm{m})$. The spores in our material agree with those provided by the latter author. The present report of $P$. michiganensis is the second in Europe; it was first reported from the Netherlands (Bronckers 2002). The Dutch collection was found on horse dung, whereas our collection was on degrading leaves, the same substrate as the holotype (Kanouse 1958).

\section{Scutellinia citrina}

- Fig. 3, f-j

Scutellinia citrina (Massee \& Cross1.) Y.J. Yao \& Spooner, Mycotaxon 53: 472. 1995.

$\equiv$ Sphaerospora citrina Massee \& Crossl., Naturalist, Hull: 4. 1904.

= Ciliaria trechispora var. paludicola Boud., Icon. Mycol., Sér. 3, Livr. 11: pl. 225. 1906.Scutellinia paludicola (Boud.) Le Gal, Bull. Soc. Mycol. France 82: 307. 1966.

Apothecia 2-5(8) mm diam, disc-shaped, sessile, gregarious, often forming groups. Margin indistinct, with short, dark brown hairs. Hymenium bright orange-red to red. Outside pale orange-red, covered with short, brown, appressed hairs. Asci cylindrical, mostly 8 -spored, sometimes with only 2 to 7 spores fully developing, $319-380 \times 33-37$ $\mu \mathrm{m}$, base pleurorhynchous. Ascospores uniseriate, globose, seldom subglobose, $\uparrow$ (19.5) 22-30.5 $\times$ (19) 23-30 $\mu \mathrm{m}\left(\mathrm{L}_{\mathrm{m}}=23.6-27.4, \mathrm{~W}_{\mathrm{m}}=23.5-27.3\right.$, $\left.\mathrm{Q}_{\mathrm{m}}=1.03, \mathrm{n}=2\right)\left[{ }^{*} 26.5-29.5 \times 26.5-29.5 \mu \mathrm{m}, 9\right.$ spores], with hemispherical warts, smaller warts intermixed with big, rarely united and elongated, up to $2.8 \mu \mathrm{m}$ high. *Content composed of many small refractive guttules; †appearing similar, de Bary bubbles present but scarce in MLZ. Paraphyses $4.3-5.7 \mu \mathrm{m}$ broad, enlarged at apices to $7.5-16 \mu \mathrm{m}$ broad, narrowly claviform to claviform, sometimes forked above, straight to slightly curved, septate. ${ }^{*}$ Content with sparse bright orange acicular crystalized matter at the apex, with pale vacuoles, at the base with small orange guttules, more abundant downwards; †with refractive small guttules, light yellowish, collapsed. Medullary excipulum of textura intricata, composed of cylindrical to slightly swollen hyphae, thin-walled, hyaline, containing refractive colourless vacuoles, 6.5-16 $\mu \mathrm{m}$. Ectal excipulum of textura globulosa, 100-150 $\mu \mathrm{m}$ thick, cells of 30-60 $\mu \mathrm{m}$, thin-walled, hyaline to light brown. Marginal hairs acute, straight or slightly curved, often bent at the apex, simple at the base, dark brown and sometimes hyaline at the apex, thickwalled, without a lumen at the apex, 0-4 -septate, 126-300 × 15-18 $\mu \mathrm{m}$. Receptacular hairs similar 
to those of the margin, thick-walled, deeply rooting, $0-3$-septate, $168-241 \times 10-14 \mu \mathrm{m}$.

Specimens studied: SWEDEN. Gotland. Stenkyrka, Lickershamn, Jungfruklint, N57.827548, E18.507736, by the sea, in wet chalky bare ground, 23.IX.2009 Hansen \& Olariaga, KH.09.197 (S). Bäl, Hejnum kallgate, N57.670991, E18.6787, on wet, chalky and clayey, bare soil, upturned and/or compressed by cow hooves, 27.IX.2009 Hansen \& Olariaga, KH.09.223, KH.09.226 (S); same locality, 29.IX.2009 Hansen \& Olariaga, KH.09.237, KH.09.239 (S); same area, $57.671318,18.677562$, on wet, chalky and clayey, bare soil, upturned and/or compressed by cow hooves, 1.X.2010 Hansen, Gillen \& Olariaga, KH.10.303 (S).

Scutellinia citrina is characterized by short hairs (Fig. 3g) and globose, warty ascospores (Fig. $3 \mathrm{i}-\mathrm{j}$ ). According to the previous records, wetlands like fens and seeping springs are the suitable habitats for $S$. citrina (Le Gal 1966, Schumacher 1990). The two Swedish localities were disturbed, very moist, bare, chalk-rich, clayey grounds. In one of them (Hejnum kallgate) a large number of fruitbodies were encountered.

Scutellinia paludicola is the name most often applied to this taxon (Le Gal 1966, Schumacher 1990, Dissing et al. 2000). Yao \& Spooner (1995) considered the type of Sphaerospora citrina to be conspecific with $S$. paludicola and made the combination in Scutellinia. As the latter authors noted, the protologue of $S$. citrina describes the hymenium colour as "amoene lutea" (Massee \& Crossland 1904). After having observed a few hundred fruitbodies, we have only seen orange red to bright red fruitbodies, as Yao \& Spooner (1995) did. At this point, despite the deceiving name, we agree with the latter authors that the colour differences are not enough to consider $S$. citrina and S. paludicola as distinct species.

Scutellinia citrina has previously been reported from one locality in Denmark and is considered rare in Norway (Dissing et al. 2000). We report it here as new to Sweden. In accordance with the Norwegian records (Schumacher 1993), the Swedish collections were made in a lowland coastal area.

\section{Scutellinia macrospora}

- Fig. 4, a-f

Scutellinia macrospora (Svrček) Le Gal, Bull. Trimestr. Soc. Mycol. France 80: 123. 1964.

$\equiv$ Lachnea lusatiae var. macrospora Svrček, Sborn. N.r. Mus. v Praze, Řada B, Př.r. Vědy 6: 58.1948.
Apothecia 1.8-5 (8) mm diam, disc-shaped, seldom shallowly cup-shaped, sometimes slightly umbilicate in the centre, sessile, gregarious, forming small groups. Margin distinct, hyaline to pale brown, with short, dark brown hairs. Hymenium bright red to orange-red. Outside orangered, covered with short, brown, appressed hairs. Anchoring hyphae abundant at the base, white. Asci cylindrical, thin-walled, 8-spored, 230-266 $\times 15-18 \mu \mathrm{m}$, base pleurorhynchous. Ascospores uniseriate, ellipsoid to fusoid, often inequelateral, with small, low rounded warts, sometimes coalescing, up to $1 \mu \mathrm{m}$ high, $\uparrow 26.5-30 \times$ 12-14 (14.5) $\mu \mathrm{m}\left(\mathrm{L}_{\mathrm{m}}=25.9-27.6, \mathrm{~W}_{\mathrm{m}}=12-13.6\right.$, $\left.\mathrm{Q}_{\mathrm{m}}=1.94-2.15 ; \mathrm{n}=8\right)[* 25-29 \times 12-14 \mu \mathrm{m}, 32$ spores]. *Content composed of small refractive guttules; †often with one or two large guttules, de Bary bubbles observed but scarce in MLZ, perispore not loosening when heated in CB. Paraphyses simple, 3-4.5 $\mu \mathrm{m}$ broad, enlarged at apices to $5-11 \mu \mathrm{m}$, narrowly claviform to claviform, straight, septate. *Content with red acicular matter at the apex, pale to bright, with abundant orange-reddish guttules at the base; † with refractive small guttules, colourless, collapsed. Medullary excipulum of textura intricata, composed of cylindrical to slightly swollen hyphae, 7-16 $\mu \mathrm{m}$, thin-walled, hyaline, with abundant refractive colourless vacuoles. Ectal excipulum of textura subglobulosa, up to $150 \mu \mathrm{m}$ thick, cells of 17-45 $\mu \mathrm{m}$, thin-walled, hyaline to light brown. Marginal hairs acute, straight, rarely bent at the apex, simple or forked at the base, light to dark brown, thick-walled $(0.5-2-[4] \mu \mathrm{m}), 0-6$-septate, $121-365 \times 14-27 \mu \mathrm{m}$. Receptacular hairs similar to those of the margin, simple or forked, 0-5 -septate, $145-290 \times 12-19 \mu \mathrm{m}$.

Specimens studied: SWEDEN. Jämtland. Åre, Handöl, on the way from Norder-Tvärån to cliffs between Tväråklumparna, alpine tundra, on a moist bank with mosses, 19.VIII.2008 Hansen \& Santos JS.08.36 (S); on soil with mosses, with Salix and Betula, on a bank, Santos \& Hansen, KH.08.36 (S). Lappland. Jukkasjärvi, Abisko, Låktatjåkka, N68.419697, E18.341718, in a wet place, on bare ground and mosses, 14.VIII.2009 Hansen \& Olariaga, KH.09.19 (S); Kopparåsen, N68.423852, E18.478382, 17.VIII.2009 Hansen \& Olariaga, KH.09.47 (S). Tärna, Vindenfjällen naturreservat, Drottningsleden, N65.815412, E15.127852, deeply placed in mosses, 17.VIII.2010 Hansen, Gillen \& Olariaga, KH.10.61 (S); Gierevaartoe, calcareous area, ground with mosses and somewhat bare ground, 20.VIII.2010 Hansen, Gillen \& Olariaga, KH.10.95 (S); same area, calcareous area, ground with mosses and somewhat bare ground, 
N65.774167, E15.083333, 20.VIII.2010 Hansen, Gillen \& Olariaga, KH.10.96 (S); same locality, among Salix herbacea in a snow bed, among mosses, 22.VIII.2010 Hansen, Gillen \& Olariaga, KH.10.123 (S); Tängvattendalen, N65.877812, E14.630785, slope by the river, on bare mull, 23.VIII.2010 Hansen, Gillen \& Olariaga, KH.10.137 (S).

Additional specimens studied: CANADA. Québec. Richmond Gulf area, $56^{\circ} 08^{\prime} \mathrm{N}, 76^{\circ} 34^{\prime} \mathrm{W}$, N-facing creek, without trees, Oxyria digyna abundant, site with running water, on ground, 31.VIII.1982 Huhtinen 82/574 (TUR).

Scutellinia macrospora can be recognized by the large ellipsoid to fusoid spores (Fig. 4d-f) and rather short, uniform hairs (Fig. 4b-c). Scutellinia mirabilis Dissing \& Sivertsen is considered to be a closely related species. It can easily be distinguished from $S$. macrospora by spores with a loosening perispore in heated CB. Both species belong to Scutellinia sect. Minutae along with $S$. superba (Velen.) Le Gal and S. torrentis (Rehm) T. Schumach. (presented below).

In spite of having studied several collections in fresh state, the content of the spores was always multiguttulate in our collections (Fig. 4f). Schumacher (1990) described the spores as "at first multiguttulate, then with two large internal guttules", without specifying if such an observation was made on living or dead material. Likewise, Jeannerot (2011) cites biguttulate spores, this time undoubtedly based on dead material collected by H. Dissing.

Our survey proved $S$. macrospora to be a rather widespread species in the Swedish mountains, as it is in Norway (Schumacher 1990). It has an arcto-boreal distribution in Norway, being frequently collected in snow beds and moist habitats in the mountains, and a montane-alpine distribution in Europe (Schumacher 1993). Nevertheless, this is the first report of the species from Sweden.

\section{Scutellinia torrentis}

- Fig. 4, g-1

Scutellinia torrentis (Rehm) T. Schumach., Opera Bot. 101: 97. 1990.

$\equiv$ Lachnea torrentis Rehm, Ann. Mycol. 5: 212. 1907.

Apothecia 1-3 mm diam, disc-shaped, seldom almost umbilicate in the centre, sessile, gregarious to weakly caespitose, forming small groups. Margin indistinct, with short, dark brown hairs. Hymenium bright orange-red. Outside orange- red, covered with short, brown, appressed hairs. Asci cylindrical, thin-walled, in general 8-spored, sometimes with aborted spores, 198-252 $\times$ 14-16 $\mu \mathrm{m}$, base pleurorhynchous. Ascospores uniseriate, broadly ellipsoid, with low rounded warts (seen on surface, not in outline), sometimes coalescing and forming small ribs, up to $0.5 \mu \mathrm{m}$ high, $\dagger 17-20.5 \times 10-12.5 \mu \mathrm{m}\left(\mathrm{L}_{\mathrm{m}}=18.8\right.$, $\left.\mathrm{W}_{\mathrm{m}}=11.5, \mathrm{Q}_{\mathrm{m}}=1.64 ; \mathrm{n}=1\right)[* 17.8-20.7 \times 10.6$ $12.8 \mu \mathrm{m}, 26$ spores]. *Content of refractive granules, central nucleus seen; †with the small guttules forming one big guttule, de Bary bubbles not seen in MLZ, with loosening perispore in heated CB. Paraphyses simple, 4-6.5 $\mu \mathrm{m}$ broad, enlarged at apices to $8-11 \mu \mathrm{m}$, narrowly claviform to claviform, straight to slightly curved, septate. ${ }^{*}$ Content with red acicular crystalized matter at the apex, hyaline towards the base, or with a few orange-reddish guttules; †with refractive small guttules, light yellowish, collapsed. Medullary excipulum of textura intricata, composed of cylindrical to slightly swollen hyphae, thin-walled, hyaline, with refractive vacuoles, up to $16 \mu \mathrm{m}$. Ectal excipulum of textura subglobulosa , 100-140 $\mu \mathrm{m}$ thick, cells of $15-55 \mu \mathrm{m}$ diam, thin-walled, light brown. Marginal hairs acute, straight, sometimes bent at the apex, simple at the base, dark brown, thick-walled $(2.5-4 \mu \mathrm{m})$, without a lumen at the apex, 0-3 septate, 200$375 \times 19.3-22.8 \mu \mathrm{m}$. Excipular hairs similar to those of the margin, with 1-2 roots, 2-4 -septate, $152-254 \times 13-17 \mu \mathrm{m}$.

Specimen studied: SWEDEN. Gotland. Bäl, Hejnum kallgate, N57.670925, E18.679306, on bare ground, upturned and/or compressed by cow hooves, small fruitbodies forming a dense group, in area with $S$. citrina, 27.IX.2009 Hansen \& Olariaga, KH.09.231 (S).

Additional specimens studied. FINLAND. Uusimaa. Pornainen. Laukkoski, Sopenmetsä, forest road, 26.X.1995 Höijer 1844 (TUR). Porvoon mlk. Kaarenkylä, clayey forest road, 5.X.1991 Höijer s.n. (TUR); sandy soil, 8.IX.1995 Höijer 1667 (TUR). GERMANY. Algäuer Hochalpen. Bei Spielmannsau, auf feinem sand im Sperrbach-Tobel, VII.1906 Krieger F6080 (Rehm's Ascomycetes 1724, isolectotype of Scutellinia torrentis, S). SWEDEN. Lappland. Villhemina, Satsfjället, bare ground with some mosses, 24.VII.2010 Schumacher, KH.10.13 (S). 


\section{Scutellinia superba}

- Fig. 4, o

Scutellinia superba (Velen.) Le Gal, Bull. Trimestr. Soc. Mycol. France 80(1): 123. 1964.

$\equiv$ Lachnea superba Velen., Monogr. Discomyc. Bohem. 1: 305. 1934.

Specimens studied: CANADA. Québec. Kuujjuarapik (= Great Whale River, Poste-de-la-Baleine), $55^{\circ} 17^{\prime} \mathrm{N}$, $77^{\circ}, 46^{\prime} \mathrm{W}$, at the rapids, on clay, 11.VIII.1982 Huhtinen 82/311 (TUR). SWEDEN. Härjedalen. Ljusnedal, V. Ruvallen, on soil, old Picea forest on calcareous soil (previously grazed forest), 7.IX.2008 Hansen KH.08.91 (S).

Here we report two, morphologically very close, species of Scutellinia, S. torrentis and S. super$b a$. Both belong to Scutellinia sect. Minutae due to the ellipsoid spores with a loosening perispore in heated $\mathrm{CB}$ and short hairs (Schumacher 1990). The description above of $S$. torrentis is based on collection KH.09.231 from Gotland. Within section Minutae, the Gotland collection can only be assigned to $S$. torrentis or $S$. superba, distinguished from each other mainly in spore size and shape. The Gotland collection, however, has spores that deviate from both of these species sensu Schumacher (1990), i.e. the spores are slightly larger than those of $S$. torrentis, and too small for $S$. superba. Additional material, including an isolectotype of $S$. torrentis, was therefore examined for comparison. The material revealed a rather high variability in the size and shape of the spores of $S$. torrentis, with a considerably broad range of $\mathrm{L}_{\mathrm{m}}=16.7-18.7 \mu \mathrm{m}$ and $\mathrm{Q}_{\mathrm{m}}=1.70-1.95$ (Table 2). Nonetheless, all the collections had spores in the range given by Schumacher in 1990 (S. torrentis: 15.6-19.2 × 7.8-11.5 $\mu \mathrm{m}$; S. superba: $19.0-23.8 \times 11.0-15.8$ $\mu \mathrm{m})$. The Gotland collection possesses slightly longer spores with higher $\mathrm{Q}_{\mathrm{m}}$ than the $S$. torrentis material used for comparison, but still shorter and with lower $\mathrm{Q}_{\mathrm{m}}$ than those of the Swedish $S$. superba collection (Table 2).

Schumacher (1990) treated Scutellinia convexa (Velen.) Svrček as a synonym of $S$. torrentis, but was not able to examine type material. The spore measures of the type obtained by Gamundí (1975, $16.8-20 \times 10.6-12 \mu \mathrm{m}$,), are larger than the ones given by Schumacher (1990), but very similar to our Gotland material. Schumacher (1990) concluded that $S$. convexa is conspecific with $S$. torrentis in spite of the difference in spore size.

Additional characters were searched for, in order to support the identification of the material.
The spore ornamentation of the typical S. torrentis collections proved to be very variable even inside one single ascus, ranging from minutely warted to incompletely and coarsely reticulate (e.g. Fig. 4m, n). The typical $S$. superba-collection (KH.08.91) had a similar variable pattern of spore ornamentation (Fig. 4o). The Gotland collection showed spores with a more regular, finely warted ornamentation (Fig. 4k-1), while coarsely warted or interconnected ribs were absent. The hairs of $S$. torrentis and $S$. superba appear to be almost identical.

We tentatively assign our KH.09.231 -collection to $S$. torrentis based on the spore characters. The Swedish collection KH.08.91 is a typical collection of $S$. torrentis, in agreement with the type collection and in the sense of Schumacher (1990). Scutellinia torrentis is reported as new to Sweden.

Scutelinia superba appears to be a rare species with only few finds reported in the world, e.g. in Norway, Denmark, the frequency and distribution in Finland is unknown (Dissing et al. 2000), Canary Islands (Korf \& Zhuang 1991) and Italy (Medardi 2007). The material of S. superba reported here is the second find in Sweden (Eriksson 2009). Huhtinen (1985) reported it from Canada, but we have been unable to verify the loosening perispore in his collection and also found the $Q_{m}$ (1.31) value of the spores to differ from $S$. superba, being broader and shorter. It would be interesting to study this material using DNA sequences and explore the species boundaries of $S$. superba and $S$. torrentis further.

\section{Spooneromyces helveticus} - Fig. 5, a-h Spooneromyces helveticus J. Breitenb. \& F. Kränzl. in T. Schumach. \& J. Moravec, Nordic J. Bot. 9: 428. 1989.

Apothecia 5-18 mm diam, shallowly cup-shaped, sessile, gregarious, forming a small group. Margin distinct, raised, with distinct, short, projecting, brown hairs. Hymenium bright orange. Outside concolorous and paler towards the base, with gradually shorter hairs towards the base. Anchoring hyphae sparse at the base. Asci cylindrical, thin-walled, 8-spored, 210-218 × 11-12 $\mu \mathrm{m}$, base pleurorhynchous. Ascospores uniseriate, ellipsoid, inequilateral, with crests that form a large-meshed reticulum, crests $2.2-3.3 \mu \mathrm{m}$ high at the poles, perispore loosening slightly at the 
poles, $\uparrow 18-20.5 \times 8.5-9 \mu \mathrm{m}\left(\mathrm{L}_{\mathrm{m}}=19.3 ; \mathrm{W}_{\mathrm{m}}=8.8\right.$; $\left.\mathrm{Q}_{\mathrm{m}}=2.2, \mathrm{n}=1\right)[* 17-19.2 \times 8.7-9.8 \mathrm{um}, 9$ spores]. $*$ Content of groups of dense granules at the poles, with central nucleus seen; † with a guttule at each pole; de Bary bubbles present in MLZ. Paraphyses 3-4 $\mu \mathrm{m}$ broad, enlarged at apices to 4.5-7 $\mu \mathrm{m}$, often branched above, straight, sparsely septate. *Content of refractive guttules only at the tips, intermixed with fine orange granules that are distributed all over the paraphyses, turning green in MLZ; †with refractive small guttules, greenish, collapsed. Subhymenium as a dense layer of subparallel hyphae, turning green-blue in MLZ. Ectal excipulum of textura globulosa, 200-220 $\mu \mathrm{m}$ thick, cells of 10-65 $\mu \mathrm{m}$, thin-walled, hyaline. Marginal hairs, straight, acute, arising from outermost cells of the ectal excipulum, with simple bases, most basal cells isodiametric, reddishbrown, hyaline at the base, with guttules inside when fresh, thick-walled (1-1.5 $\mu \mathrm{m}), 4-12$-septate, $123-380 \times 18-24 \mu \mathrm{m}$. Receptacular hairs similar to those of the margin, scarcer, shorter. Hyphal hairs intermixed with receptacular hairs, filiform, flexuous, slightly thick-walled (up to 1 $\mu \mathrm{m})$, hyaline, septate, 4-9 $\mu \mathrm{m}$ diam.

Specimen studied: SWEDEN. Jämtland. Åre, Handöl, Vålådalens naturreservat, near Kronstugan by Ånnsviken, under Picea in rich soil, with remains of elk hairs, 18.VIII.2008 Santos \& Hansen, JS.08.30 (S).

\section{Spooneromyces laeticolor}

Spooneromyces laeticolor (P.Karst.) T. Schumach. \& J. Moravec, Nordic J. Bot. 9: 427. 1989.

Specimen studied: SWEDEN. Pite Lappmark. Arvidsjaurs, Avlångbäcken Allmänningreservat, $8 \mathrm{Km}$ VNV Järvträsk, $330 \mathrm{~m}$ a.s.l., rich Picea forest, on needle litter, 11.IX.2009 Karström 0939 (S).

The genus Spooneromyces T. Schumach. \& J. Moravec was described to accommodate species with bright orange apothecia, moderately thickwalled, non-fasciculate, multiseptate, acute hairs that arise from the outer cells of the excipulum (Schumacher \& Moravec 1989). Two species were initially included in the genus, $S$. helveticus and $S$. laeticolor. Two additional species have since then been assigned to Spooneromyces, namely $S$. daliensis (W.Y. Zhuang) W.Y. Zhuang (2005) and S. microsporus Jamoni (2008).

Here we report Spooneromyces as a genus new for Sweden, with two species new for the country: S. helveticus and S. laeticolor. Originally described from Switzerland (Breitenbach \& Kränzlin 1984 as Melastiza sp., Schumacher \& Moravec 1989), S. helveticus has subsequently been recorded from a second Swiss locality (Baiano et al. 2000), France (Moyne et al. 2010) and Germany (Benkert 2010). This is the first record of $S$. helveticus for the Nordic countries. The material conforms to the original description in every aspect. In addition, the subhymenium and medullary excipulum turn strikingly greenish blue when mounted in MLZ. Interestingly, the same reaction was observed in Swedish material of S. laeticolor, and Zhuang (2005) reported it for $S$. daliensis. This reaction has not been consistently checked in related genera, and further observations should be made before evaluating its taxonomical value.

Spooneromyces laeticolor seems to be a rare species, reported only a few times in e.g. England (Spooner 1981, sub Melastiza asperula), Finland, Norway, Denmark, Spain (Schumacher \& Moravec 1989) and Austria (Jeannerot 2010). The Swedish record is the northernmost occurrence so far.

Acknowledgements: This project was funded by a grant from the Swedish Taxonomy Initiative to KH (grant no. 143/07 1.4). We thank Juan Santos and Kerstin Gillen for their participation in the Swedish Pezizomycetes project during part of 2008 and 2010, respectively. We are also grateful to Mats Karström for having collected the first Swedish record of Spooneromyces laeticolor; the curator of TUR, Seppo Huhtinen, for arranging the loan of reference material; Donald Pfister for sending photos of his anatomical sections of Paratrichophaea michiganensis for comparison and providing some old literature; and Beñat Jeannerot, Ron Bronckers and Young Joon Choi for their kindness and helpful comments. 

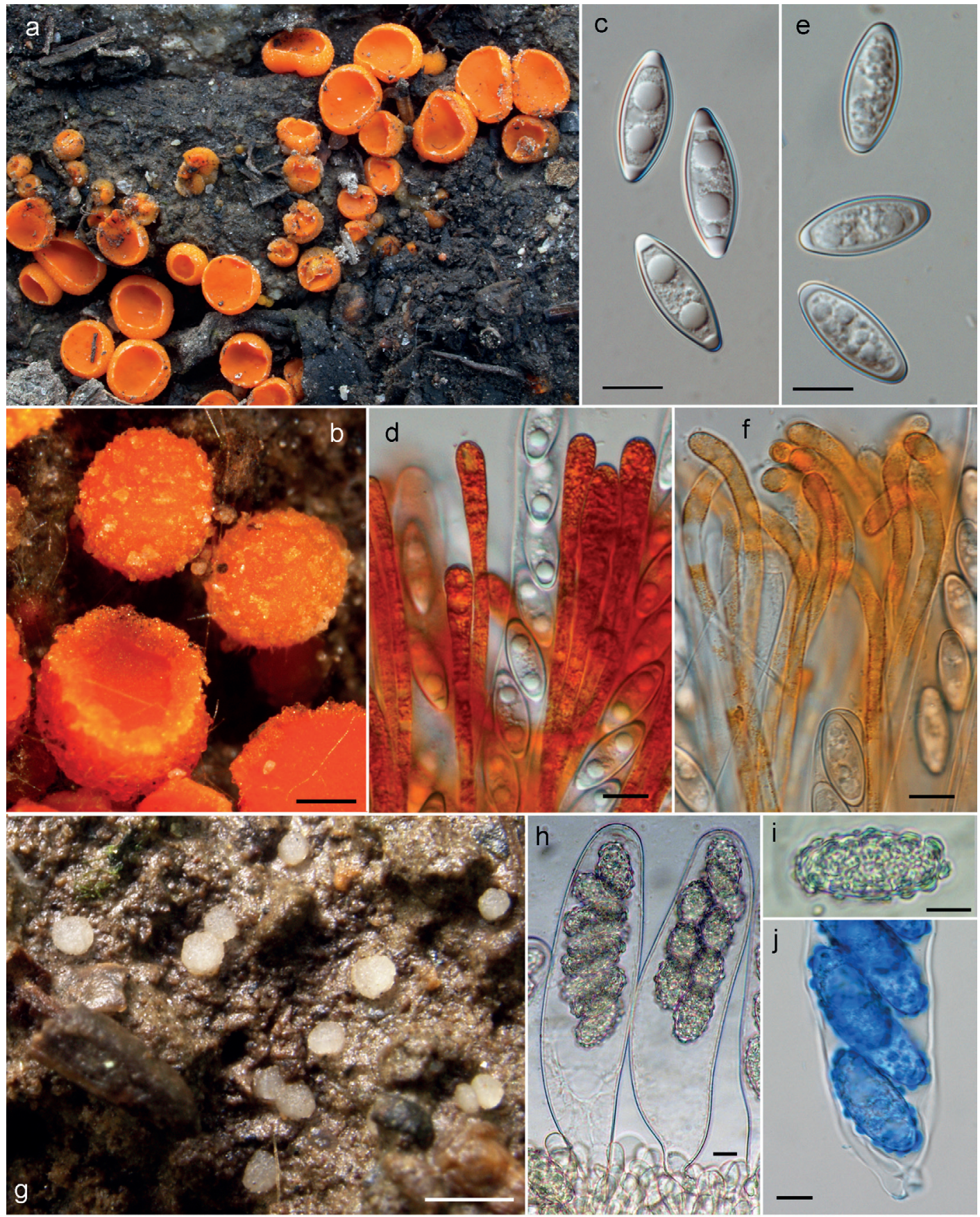

Fig. 1. Byssonectria and Chalazion. $\mathrm{a}-\mathrm{d}=$ B. fusispora $(K H .10 .06$, except $\mathrm{a}=K H .10 .01), \mathrm{a}=$ apothecia, $\mathrm{b}=$ young apothecia, two still closed and one open showing the hymenium and rimmed margin, with small scales on outside, $c$ $={ }^{*}$ spores in DIC, $\mathrm{d}={ }^{*}$ paraphyses. $-\mathrm{e}-\mathrm{f}=B$. terrestris $\left(\right.$ KH.10.06). $\mathrm{e}={ }^{*}$ spores in $\mathrm{DIC}, \mathrm{f}=*$ paraphyses. $-\mathrm{g}-\mathrm{j}=C$. sociabile (KH.09.70), $\mathrm{g}=$ apothecia, $\mathrm{h}=*^{*}$ clavate asci, $\mathrm{i}=*$ free spore, $\mathrm{j}=+$ short pleurorhynchous base of ascus with spores in CB. Scale $=10 \mu \mathrm{m}$, except b $(0.2 \mathrm{~mm})$ and $\mathrm{g}(\mathrm{ca} 1 \mathrm{~mm})$. Photos: a, c, d, g-i Olariaga; b, e, f, j Hansen. 


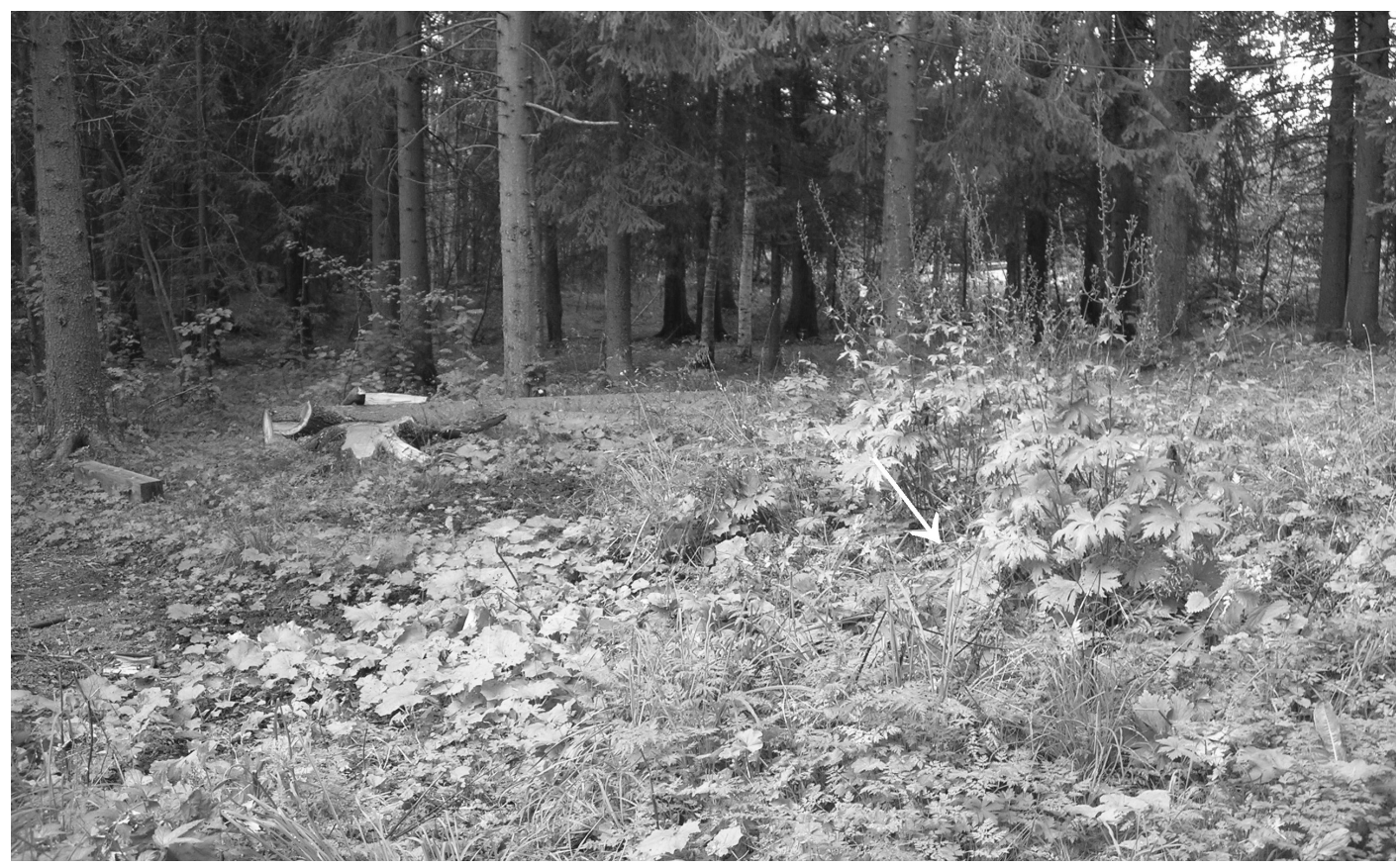

Fig. 2. Collecting site of Chalazion sociabile (KH.09.70). The arrow indicates the exact spot where the apothecia were collected. Photo: Olariaga.

Table 1. Distinguishing characters of Byssonectria fusispora and B. terrestris

\begin{tabular}{|l|l|l|}
\hline & B. fusispora & B. terrestris \\
\hline Growth manner & Gregarious to weakly caespitose & Densely caespitose \\
\hline Apothecia shape as mature & Shallowly cup-shaped & Turbinate and disc-shaped \\
\hline Subiculum & Inconspicuous hyphal threads & Thick and white mat \\
\hline Ascospore size* & $23-25.5 \times 7-8 \mu \mathrm{m}$ & $21.5-23 \times 8.5-9.5 \mu \mathrm{m}$ \\
\hline Ascospore size $\dagger$ & $21-24.5 \times 7-8.5 \mu \mathrm{m}$ & $21.5-24 \times 8.2-9.5 \mu \mathrm{m}$ \\
\hline Paraphyses shape & Straight to slightly bent & Bent \\
\hline Ecology & Old burnt area on acidic ground & Urine and dung of elk \\
\hline
\end{tabular}

Table 2. Statistics of dried spore measurements of Scutellinia torrentis and S. superba.

\begin{tabular}{|l|l|l|l|l|l|}
\hline Species & Coll. no. & $\mathrm{Lm}(\mu \mathrm{m})$ & Wm $(\mu \mathrm{m})$ & $\mathrm{Qm}$ & No. spores \\
\hline S. torrentis & KH.09.231 & 18.8 & 11.5 & 1.64 & 20 \\
\hline S. torrentis & TUR 153426 & 17.7 & 9.9 & 1.79 & 13 \\
\hline S. torrentis & TUR 153436 & 18.7 & 9.6 & 1.95 & 14 \\
\hline S. torrentis & F-6080 & 18.2 & 10.7 & 1.70 & 20 \\
\hline S. torrentis & TUR 153438 & 18.5 & 10.0 & 1.85 & 20 \\
\hline S. torrentis & KH.10.13 & 16.7 & 9.6 & 1.74 & 20 \\
\hline S. superba & KH.08.91 & 21.0 & 14.3 & 1.47 & 20 \\
\hline
\end{tabular}



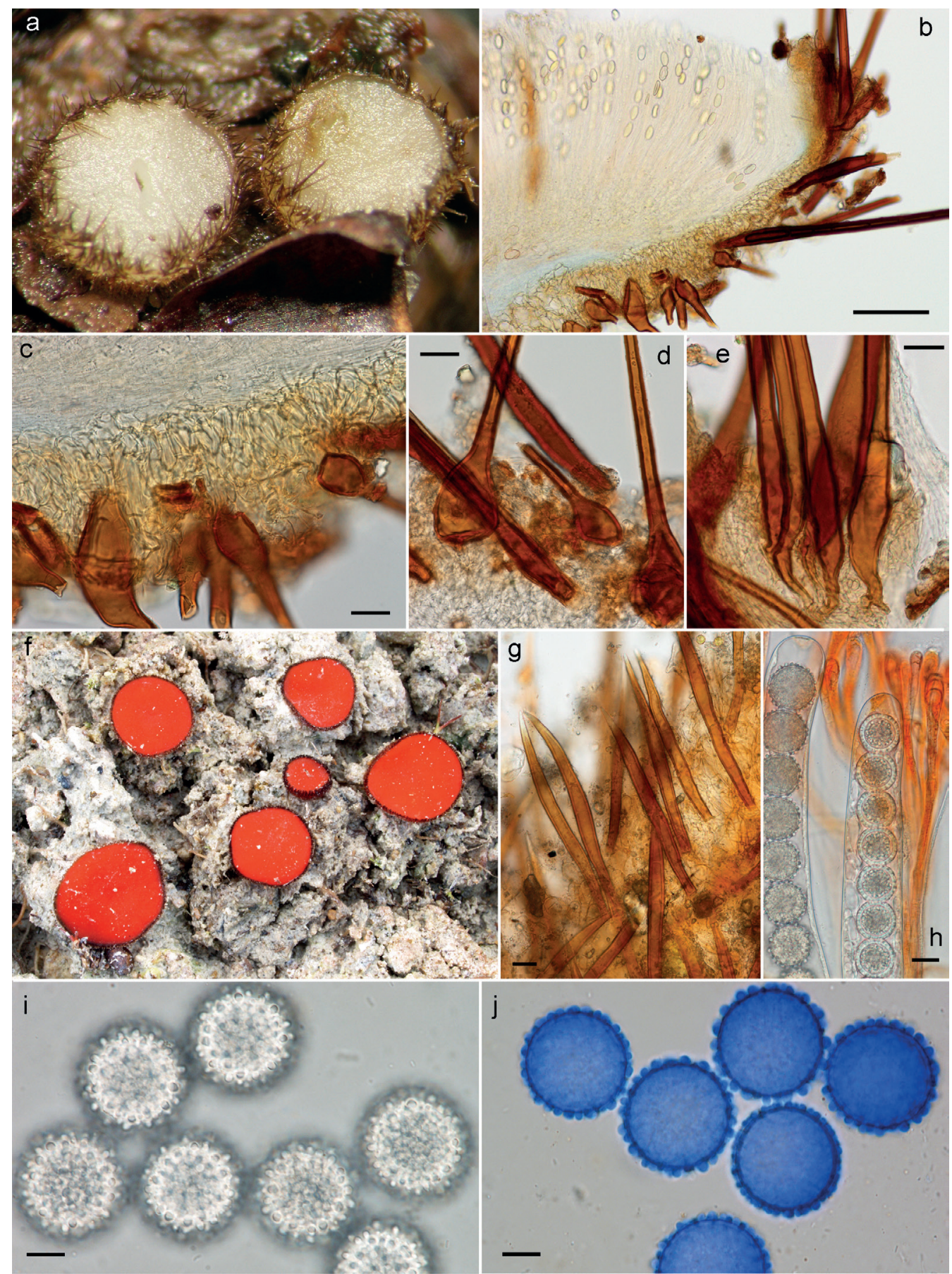

Fig. 3. Paratrichophaea and Scutellinia. $\mathrm{a}-\mathrm{e}=P$. michiganensis $(K H .10 .244), \mathrm{a}=$ apothecia, $\mathrm{b}=+$ transverse section of an apothecium, showing the margin, $\mathrm{c}=\dagger$ section of the ectal excipulum showing rooting hairs and weakly blueing medullary excipulum in MLZ, $\mathrm{d}=\dagger$ hairs with bulbous bases in a piece taken from the outside, towards the base of an apothecium, $\mathrm{e}=\dagger$ simple bases of hairs. $-\mathrm{f}-\mathrm{j}=S$. citrina $(K H .09 .223$, except $f=K H .09 .237), \mathrm{f}=$ apothecia, $\mathrm{g}=\dagger$ short excipular hairs, $\mathrm{h}=*$ asci with immature and mature spores and paraphyses, $\mathrm{i}=*$ free spores, $\mathrm{j}=$ spores in $\mathrm{CB}$, in outline. Scale $=10 \mu \mathrm{m}$, except c, d, e, g $20 \mu \mathrm{m}$. Photos: a, d-f Olariaga; b, c, g-j Hansen. 

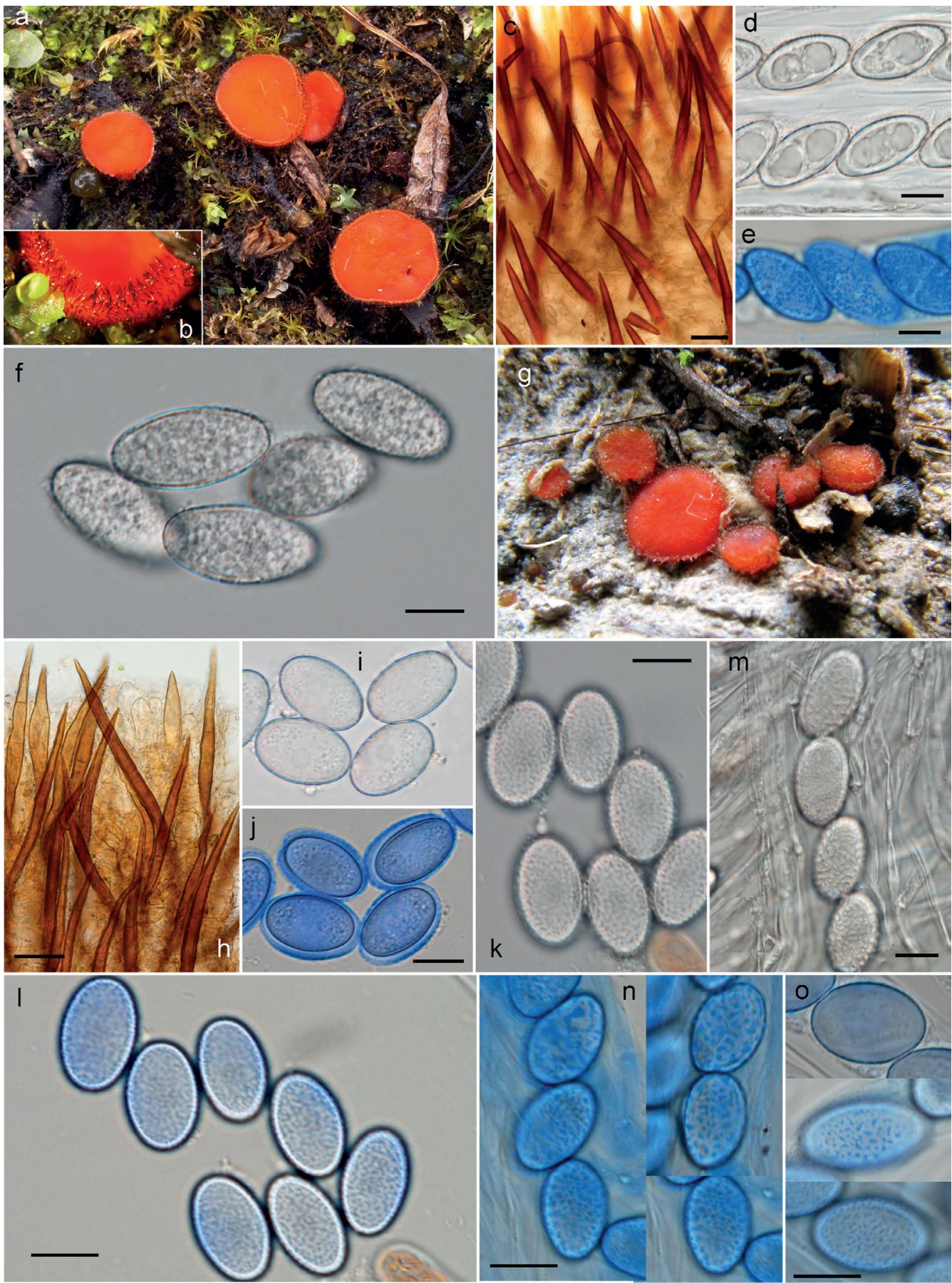

Fig. 4. Scutellinia. a- $\mathrm{f}=$ S. macrospora $(J S .08 .36$, except $a=K H .09 .96 ; b, f=K H .08 .36)$, $\mathrm{a}=$ apothecia, $\mathrm{b}=$ close-up of short marginal hairs, $\mathrm{c}=$ short hairs, $\mathrm{d}=\uparrow$ spores with 2 large guttules, $\mathrm{e}=\uparrow$ spores in $\mathrm{CB}$ showing fine warts, $\mathrm{f}=$ *multi-guttulate free spores. $-\mathrm{g}-\mathrm{l}=S$. torrentis $(K H .09 .231$, except $m, n=S$ F-6080, isolectotype), $\mathrm{g}=$ apothecia, $\mathrm{h}$ $=$ short hairs, $\mathrm{i}=*$ spores with small guttules, outline, $\mathrm{j}=$ spores with loosening perispore in heated $\mathrm{CB}, \mathrm{k}=$ * spores, $^{2}$ ornamentation, $\mathrm{l}=$ spores with cyanophilous ornamentation in $\mathrm{CB}, \mathrm{m}=\uparrow$ spores in DIC, ornamentation, $\mathrm{n}=$ spores, in part with loosening perispore (photo on the left), in heated CB. - S. superba $($ KH.08.91), o $=\uparrow$ spores in CB. Scale $=$ $10 \mu \mathrm{m}$, except c, h $50 \mu \mathrm{m}$. Photos: a, c, d, n, o Olariaga; b, e, f-m Hansen. 

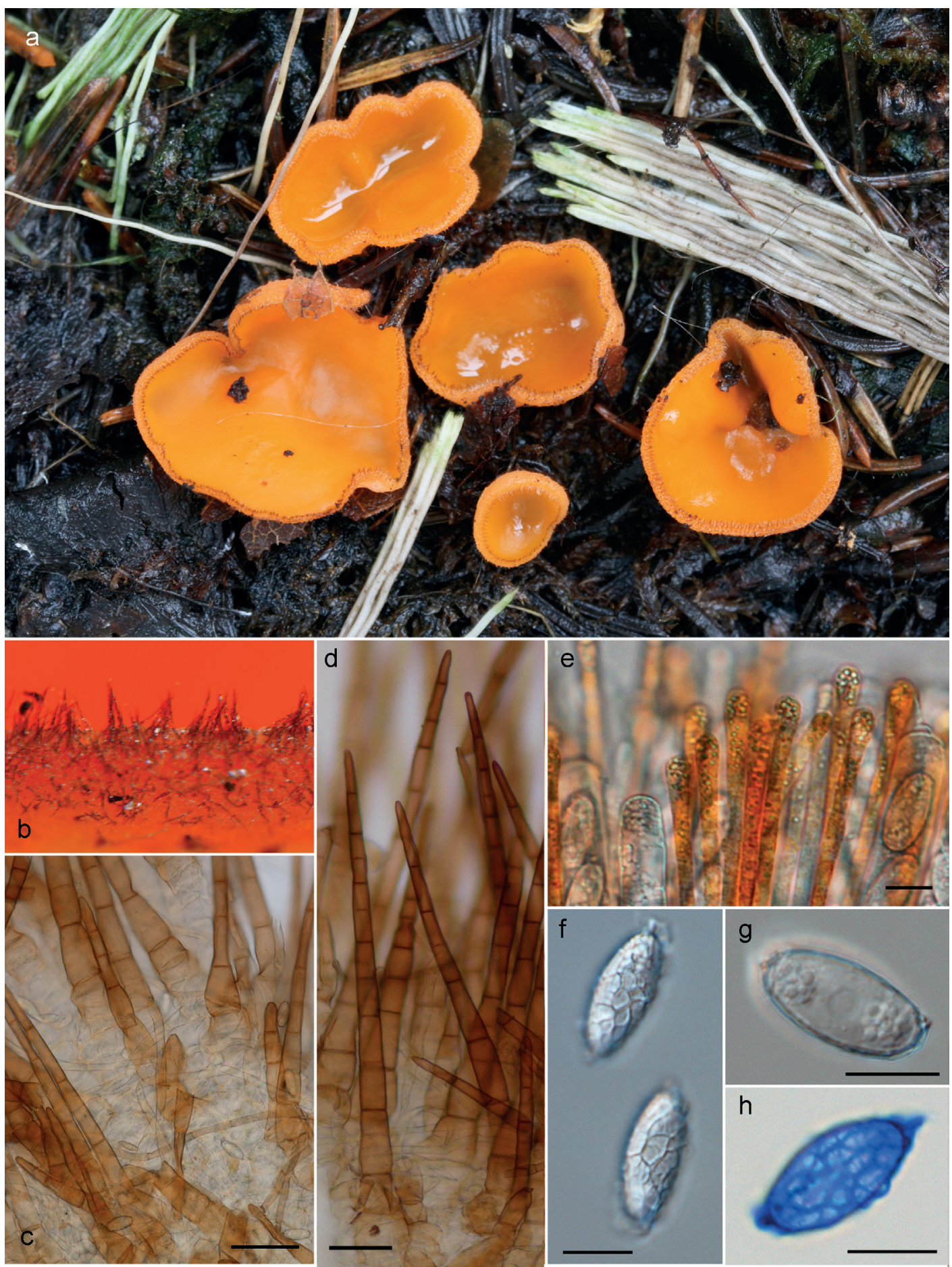

Fig. 5. Spooneromyces helveticus (JS.08.30), a $=$ apothecia, $\mathrm{b}=$ close-up of marginal, projecting hairs, $\mathrm{c}=\dagger \mathrm{base}$ of receptacular hairs and hyphal hairs in between, $\uparrow \mathrm{d}=$ receptacular hairs arising from the outermost cells of the ectal excipulum, $\mathrm{e}=*$ paraphyses apices, with refractive guttules and tiny orange granules, $\mathrm{f}=*$ spores showing the ornamentation in DIC, $\mathrm{g}=*$ spore content, $\mathrm{h}=$ spore with cyanophilous ornament in CB. Scale $=10 \mu \mathrm{m}$, except $\mathrm{c}, \mathrm{d} 20 \mu \mathrm{m}$. Photos: a Juan Santos; b, e-h Hansen; c, d Olariaga. 


\section{References}

Baiano, G., Garofoli, D. \& Filippa, M. 2000: Ascomiceti interessanti del Nord Italia. - Fungi non Delineati 12: $1-74$

Baral, H.O. 1992: Vital versus herbarium taxonomy: Morphological differences between living and dead cells of Ascomycetes, and their taxonomic implications. - Mycotaxon 44: 333-390.

Benkert, D. 1987: Bemerkenswerte Ascomyceten aus der DDR. IX. Die Gattung Byssonectria. - Gleditschia 15: 173-187.

Benkert, D. 2010: Seltene und kritische Pezizales-Funde (Ascomycota) aus der Bundesrepublik Deutschland. Zeitschrift für Mykologie 76: 27-58.

Berkeley, M.J. 1846: Decades of fungi. Decade XI. - The London Journal of Botany 5: 1-6.

Berkeley, M.A. \& Broome, C.E. 1866: Notices on British fungi. - Annals and Magazine of Natural History, Ser. 3, 18: 121-129.

Boudier, J. L. É. 1905-10: Icones Mycologicae. 4 vols. Paul Klincksieck, Paris.

Breitenbach, J. \& Kränzlin, F. 1984: Fungi of Switzerland. Volume 1. Ascomycetes. - Verlag Mykologia. Luzern. Switzerland.

Bronckers, R.J.C. 2002: Paratrichophaea macrocystis en Paratrichophaea michiganensis, twee zeldzame pelsbekertjes op mest van grote grazers in Zuild-Limburg. - PSL Nieuws 9: 5-9.

Bronckers, R.J.C. 2003: Een sleutel tot de Europese soorten van de genera Trichophaea, Trichophaeopsis en Paratrichophaea. - Sterbeeckia 23: 9-27.

Dissing, H. 1966: The genus Helvella in Europe with special emphasis on the species found in Norden. - Dansk Botanisk Arkiv 25: 1-172.

Dissing, H. 1980: Chalazion helveticum (Pezizales), a new species from Graubünden, Switzerland. Sydowia 33: 29-32.

Dissing, H. 1983: Tre nye bægersvampe (Pezizales) i Danmark. - Svampe 7: 43-45.

Dissing, H. \& Sivertsen, S. 1975: Operculate Discomycetes from Rana (Norway) 1. Chalazion sociabile gen. nov., sp. nov. - Norwegian Journal of Botany 22: 1-4.

Dissing, H. \& Sivertsen, S. 1983: Operculate Discomycetes from Rana (Norway) 4. Octospora hygrohypnophila, Peziza prosthetica and Scutellinia mirabilis spp. nov. - Nordic Journal of Botany 3: 415-421.

Dissing, H. \& Schumacher, T. 1994. Pezizales. - In: Hawksworth, D.L. (ed.). Ascomycete systematics: problems and perspectives in the nineties, 397-401. Plenum Press, New York.

Dissing, H., Eckblad, F.-E. \& Lange, M. 2000: Pezizales Bessey. - In: Hansen, L. \& Knudsen, H. (eds.). Nordic Macromycetes. Vol. 1. Ascomycetes, 55-127. Nordsvamp, Copenhagen.

Doveri, F., Yei-Zeng, W., Cacialli, G. \& Vincenzo, C. 1998: Una nuova specie di Chalazion dalla Toscana, Italia. Contributo allo studio dei funghi fimicoli. XXVIII. - Rivista di Micologia 3: 203-209.

Eckblad, F.-E. 1968: The genera of the Operculate Discomycetes. A Re-evaluation of their Taxonomy, Phylogeny and Nomenclature. - Nytt Magasine for Botanikk 15: 1-191.
Eriksson, O. E. (ed.). 1999: Outline of Ascomycota. Myconet 3: 1-88.

Eriksson, O. E. (ed.). 2000: Notes on ascomycete systematics. Nos 2940-3127 - Myconet 5: 1-35.

Eriksson, O.E. 2009: The non-lichenized ascomycetes of Sweden. - Umeå University. Sweden.

Gamundí, I.J. 1975: Flora criptogámica de Tierra del Fuego. Orden Pezizales. Tomo X. Fascículo 3. - Fundación para la Educación, la Ciencia y la Cultura. Buenos Aires. Argentina.

Hansen, K., Perry, B.A. \& Pfister, D.H. 2005: Phylogenetic origins of two cleistothecial fungi, Orbicula parietina and Lasiobolidium orbiculoides, within the operculate discomycetes. - Mycologia 97: 1023-1033.

Hansen, K. \& Pfister, D.H. 2006 [2007]: Systematics of the Pezizomycetes - the operculate discomycetes. Mycologia 98: 1031-1041.

Harmaja, H. 2009: Studies in Otidea (Pezizales). Karstenia 48: 33-48.

Huhtinen, H. 1985: Mycoflora of Poste-de-la-Baleine, Northern Québec. Ascomycetes. - Naturaliste Canadien 112: 473-524.

Jamoni, G. 2008: Una nuova entità dalla Valsesia: Spooneromyces microsporus sp. nov. - Funghi e Ambiente 108: 5-9.

Jeannerot, B. 2010: Notes on scutellinioid fungi in collections of the Vienna University herbarium (WU). Österreichische Zeitschrift Für Pilzkunde 19: 19-29.

Jeannerot, B. 2011: Sur deux récoltes de Scutellinia macrospora effectuées par Henry Dissing. - Ascomycete. org 2(4): 23-26.

Kanouse, B.B. 1958: Some species of the genus Trichophaea. - Mycologia 50: 121-140.

Korf, R. 1973: Discomycetes and Tuberales. - In: Ainsworth, G.C., Sparrow, F.K. \& Sussman, S. (eds.). The fungi. And advanced treatise. Vol. 4A: 249-319. Academic Press. New York.

Korf, R.P. \& Zhuang, W.-Y. 1991: A preliminary discomycete flora of Macaronesia: Part 1, Otideaceae, Scutellinioideae. - Mycotaxon 40: 79-106.

Kristiansen, R. 1990: New records of species of the genus Chalazion (Pezizales) in Norway with emphasis on their ecology. - Agarica 19-20: 83-97.

Kristiansen, R. 2006: Miniatyrbegersopper nye for Norge. - Agarica 26: 69-77.

Landvik, S.; Winka, K. \& Schumacher, T. 1998: Longtime storage of fresh fungal tissue in DNA preparation buffer. - Proceeding of the Asia-Pacific Mycological Conference on Biodiversity and Biotechnology: 177181. Thailand.

Le Gal, M. 1966: Contributiom a la connaissance du genre Scutellinia (Cooke) Lamb. emend. Le Gal ( $1^{\text {re Étude). }}$ - Bulletin Trimestriel de la Société Mycologique de France 82: 301-334.

Massee, G.E. \& Crossland, C. 1904: Sphaerospora citrina Mass. et Crossl. (sp. nov.). In: Anonymous, New Fungi. - Naturalist, London, Huddersfield, Hull 564: 4-5 pp.

Medardi, G. 2007: Il genere Scutellinia in Italia - Mycologia Montenegrina 10: 119-164.

Moyne, G., Chaillet, P., Moingeon, P.-M., Frund, C. \& Page, C. 2010: Deux ascomycétes rares, nouveaux pour la France: Smardaea purpurea et Spooneromyces helveticus (Ascomycota, Pezizales). - Bulletin mycologique et botanique Dauphiné-Savoie 196: 7-15. 
Nannfeldt, J.A. 1937: Contributions to the mycoflora of Sweden 4. On some species of Helvella, together with a discussion of the natural affinities within Helvellaceae and Pezizaceae trib. Acetabuleae. - Svensk Botanik Tidskrift 31: 47-66.

Nannfeldt, J.A. 1938: Contributions to the mycoflora of Sweden. 5. On Peziza catinus Holmskj. ex Fr. and P. radiculata Sow. ex Fr. with a discussion of the genera Pustularia Fuck. emend. Boud. and Sowerbyella Nannf. n. gen. - Svensk Botanik Tidskrift 32: 108-120.

Nannfeldt, J.A. 1949: Contributions to the mycoflora of Sweden 7. A new winter discomycete, Urnula hiemalis Nannf. n. sp., and a short account of the Swedish species of Sarcoscyphaceae - Svensk Botanik Tidskrift 43: 468-484

Nannfeldt, J.A. 1966: On Otidea caligata, O. indivisa and O. platyspora (Discomycetes Operculatae). - Annales Botanici Fennici 3: 309-318.

Petersen P.M. 1985: The ecology of Danish soil inhabiting Pezizales with emphasis on edaphic conditions. - Opera Botanica 77: 1-38.

Pfister, D.H. 1988: Paratrichophaea (Pezizales) in North America. - Mycologia 80: 515-519.

Pfister, D.H. 1993: A synopsis of the North American species of Byssonectria (Pezizales) with comments on the ontogeny of two species. - Mycologia 85: 952-962.

Rifai, M.A. 1968: The Australasian Pezizales in the herbarium of the Royal Botanic Gardens Kew. - Verhhandlingen der Koninklijke Akademie van Wetenschappen. Afdeeling Natuurkunde 57: 1-295.

Schumacher, T. 1979: Notes on taxonomy, ecology and distribution of operculate discomycetes (Pezizales) from river banks in Norway. - Norwegian Journal of Botany 26: 53-83.

Schumacher, T. 1990: The genus Scutellinia (Pyronemataceae). - Opera Botanica 101: 1-107.

Schumacher, T. \& Moravec, J. 1989: Spooneromyces, a new genus to accommodate Peziza laeticolor and the new species S. helveticus. - Nordic Journal of Botany 9: 425-430.

Schumacher T. \& Jenssen, K.M. 1992: Discomycetes from the Dovre mountains, Central South Norway. In Arctic and alpine fungi - 4. - $66 \mathrm{pp}$. Soppkunsulenten A/S. Oslo.

Schumacher, T. 1993: Ecology and distribution of the genus Scutellinia in Norway. In: Petrini, O. \& Laursen, G.A. (eds.). Arctic and alpine Mycology 3. - Bibliotheca Mycologica 150: 215-233.

Spooner, B.M. 1981: New records and species of British microfungi. - Transactions of the British Mycological Society 76: 265-301.

Svrček, M. 1969: Nové rody operculatních diskomycetu (Pezizales). - Česká Mykologie 23: 83-96.

Yao, Y-J. \& Spooner, B.M. 1995: New combinations in Melastiza and Scutellinia (Pezizales). - Mycotaxon 52: $467-477$.

Yao, Y-J. \& Spooner, B. M. 1996: Notes on British species of Byssonectria. - Mycological Research 100: 881-882.

Zhuang, W.-Y. 2005: Some new species and new records of discomycetes in China. - Mycotaxon 93: 99-104. 